\title{
Biodiversity Indicators for Sustainability Evaluation of Conventional and Organic Agro-ecosystems
}

\author{
Paola Migliorini*, Concetta Vazzana \\ Dipartimento di Scienze Agronomiche e Gestione del Territorio Agroforestale, Università di Firenze \\ Piazzale delle Cascine 18, 50144 Firenze, Italy
}

Received: 2 December 2006. Accepted: 2 January 2007

\begin{abstract}
Previous studies suggest widespread positive responses of biodiversity to organic farming. However, the effect of organic farming management on biodiversity over time needs to be better understood and this paper aims to compare agricultural biodiversity in a long-term experiment including three different agroecosystem management patterns (old organic, young organic and conventional). The level of agroecosystem sustainability related to plants has been assessed both for the structural and the associated biodiversity, using biodiversity Indicators. The data collected in three years (2003-2005) show that the system under organic agriculture management is better than conventional one for every indicator and it improves each aspect over the time. This trend holds especially for the associated biodiversity while the planned biodiversity can still be improved.
\end{abstract}

Key-words: biodiversity, sustainability indicators, organic vs conventional agriculture.

\section{Introduction}

Biodiversity in farms refers to all plant and animal organisms present in and around farms that interact as components of an agroecosystem (Nicholls and Altieri, 2005) and implements many different functions: biomass decomposition, nutrient cycling, soil structure enhancement, pest regulation, pollination, detoxification, local idrological process regulation and macroclimate control (Altieri, 1999). Biodiversity components of farms can be classified in relation to the role they play in the functioning of cropping systems, as follows:

- Productive biota: crops and livestock chosen by the farmers. They depend on the farm organisation (spatial and temporal) and the intensity of management (type and quantity of input and output). This component can be classified as structural or planned biodiversity;

- Resource biota: organisms that contribute to productivity with positive functions (pollination, pest regulation, decomposition);

- Destructive biota: organisms (weeds, pest in- sects, pathogens, etc.) that obstacle productivity with damaging functions.

The latter two, can also be classified as associated biodiversity since they colonize the farm from the surrounding environments and influence the agroecosystem depending on its management. Thus, agricultural practices are directly involved either in the construction or in the maintenance of a certain level of desired biodiversity.

If organic agriculture is based on correct managements, it increases the agrobiodiversity components (Stolze et al., 2000; Stolton, 2005) and more biodiversity provides a fundamental service for natural control of pest and disease, soil fertility improvement and stability of production.

The use of sustainability indicators has become a frequent instrument in the evaluation of both biodiversity and agricultural systems (Bockstaller et al., 1997; Dalsgaard and Oficial 1997; Morse et. al 2001; Lopez-Ridaura et al. 2002; Caporali et al., 2003) especially when the comparison of organic vs conventional methods

\footnotetext{
* Corresponding Author: Tel. +39 055 3288252; Fax: +39 055 332472. E-mail address: paola.migliorini@unifi.it
} 
is performed, both in commercial farms (Migliorini, 2000; Pacini et al., 2003) and in experimental long term experiments (LTE) (Leight and Jhnston, 1994; Mäder, et al. 2002; Pimentel et al., 2005; Raupp et al. 2006).

A large number of studies have developed biotic indicators for evaluation of biodiversity in sustainable agriculture. A significant pilot research study, entitled 'European network for the planning and the management of Ecological and Integrated Arable Farming System (E/IAFS)' (Vereijken, 1997 and 1999; Vazzana et al., 1997) which aimed at the evaluation of sustainability using a systemic approach, provided an important contribution both for the definition of a reference frame for agro-environmental indicators and for the assessment of a prototype agroecosystem methodology.

Comparative researches on biodiversity in conventional and organic systems show that 66 over 76 studies show positive effect of organic farming on individual taxon of birds, mammals, butterfly, spider, earthworms, beetles, other arthropods, plants, soil microbes, in comparison to conventional (Hole et al., 2005). These studies review that some agricultural practices (prohibition/reduction of chemicals pesticide and inorganic fertilisers; managements of non-cropped habitat; preservation of mixed farming) are beneficial to a wide range of taxa and in particular to farmland wildlife. However, both for methodological and for the spatial and temporal dimension of analysis, the potential role of biodiversity in organic farming needs to be better understood and this paper aims to describe agricultural biodiversity under different farm managements.

\section{Materials and methods}

The experimental area is in the farm of the University of Florence (Montepaldi) situated in the municipality of S. Casciano, Val di Pesa, FI (Long. $11^{\circ} 09^{\prime} 08^{\prime \prime}$ E, Lat. 43 40' 16” N.). A biodiversity sustainability evaluation has been applied to the Montepaldi Long Term Organic Experiment (MOLTE) active since 1991. MOLTE includes the following three different micro agro-ecosystems (AES):

a) "Old Organic" area of 5.2 ha, divided into 4 fields, organic since 1991;

b) "Young Organic" area of 5.2 ha, divided into 4 fields, organic since 2001; c) "Conventional" area of 2.6 ha divided into 2 conventional fields.

Each field covers 1.3 hectares $(260 \mathrm{~m}$ x 50 $\mathrm{m})$. The agroecosystems are surrounded by the following ecological infrastructures: 1) old organic: natural and artificial hedges; 2) young organic: natural hedges and herbaceous strips of spontaneous flora; 3 ) conventional: herbaceous strips of spontaneous flora). Following the local land use, a four-year crop rotation is adopted in the organic agro-ecosystems: green manure $($ barley + vetch $)+$ corn - hard wheat + red clover - red clover - barley; whilst a biennial rotation (barley - corn) is adopted in the conventional agroecosystem.

In order to evaluate the sustainability of the different agroecosystems (old organic, young organic and conventional), the level of biodiversity related to plants has been assessed according to the following aspects: 1) for the structural biodiversity: landscape and crop rotation; 2) for the associated biodiversity: vegetation.

The collected data refer to the period 20022005 (Migliorini, 2006). Different agro-ecological indicators characterize different aspect of biodiversity, in order to estimate a specific attribute of the system (Tab. 1). For each single indicator, an optimal (desirable) reference value was selected from the literature (Vereijken, 1997; Vazzana et al., 1997; Caporali et al., 2003), taking into consideration the territorial context and in agreement with the threshold (minimal) level that is in compliance with the EU Reg. 2092/91 and following modifications and integrations.

The landscape within the farm was evaluated through the following indicator

- ecological infrastructure index (EII). Farm area with herbaceous, shrubs and tree vegetation, both natural/untouched and planted/managed, can serve as natural habitat and corridors (ecological infrastructures) for agroecological and landscape purpose.

For the evaluation of crop rotation the following indicators were calculated:

- crop rotation (CR). Species diversity in space and time is the base for sustainable agriculture. The crop rotation of farming systems is defined in relation to many factors like environment, climate, soil, resources, market. Some methodologies (Vereijken, 1997; Vazzana et al., 1997) indicate 6 years as minimum value; 
- species adjacency (SA). It refers to the diversification of the crop rotation with different crop every year (Vereijken, 1997);

- share species (SS) and share group (SG). They indicate the percentage of certain species and botanical groups within the crop rotation respectively. The prevalence of a specie or group has to be limited (Vereijken, 1997) to avoid homogeneity.

The associated biodiversity was evaluated through the following indicators:

- ecological infrastructure arboreal richness (EIRa) and ecological infrastructure herbaceous richness (EIRh). The number of vegetable species present in shrubs and arboreal (hedges) ecological infrastructures (Fig. 1);

- ecological infrastructure arboreal diversity (EIDa). For the analysis of tree species in the ecological infrastructures the BraunBlanquet method (Braun Blanquet, 1932) has been used. Covering percentages of botanical composition were attributed to each hedge section (Capelletti, 1976). These indexes were transformed (Van der Maaler, 1972) in order to calculate the Shannon Diversity index (Shannon and Weaver, 1963);

- ecological infrastructure herbaceous diversity (EIDh). For the analysis of herbaceous species in the ecological infrastructure a linear analysis (Daget and Passionale, 1969) was used. Within each sample, the number of individual for each species was determined every 20 meters along a transect (Fig. 2). The Shannon diversity index was calculated;

- crop weeds (number) diversity (CWDn) and crop weeds (biomass weight) diversity (CWDw). At crop level - in this case maize - the spontaneous flora was sampled in the experimental field, botanically classified, dried and weighted (Migliorini et al., 2005). The collected data are the following: weed density ( $\mathrm{n}$. of plant $\mathrm{m}^{-2}$ ); biomass of each species $\left(\mathrm{gr} \mathrm{m}^{-2}\right)$. With these data is possible

Figure 1. List of vegetable species founded in hedges of Montepaldi agroecosystems.

Acer campestre, Clamatis vitalba L., Cornus sanguinea L., Crategus monogyna Jacq., Fraxinus ornus, Populus alba L., Prunus spinosa L., Pyrus pyraster, Quercus cerri, Robinia pseudoacacia, Rosa canina L., Rubus ulmifolius, Ulmus campestre.
Figure 2. List of vegetable species founded in herbaceous strips of Montepaldi agroecosystems.

Acer campestre, Adonis aestivalis, Amaranthus deflexus, Amaranthus retroflexus, Anagallis arvensis, Atriplex papula, Avena fatua, Bambuseae, Biancospino, Bromus Hordeaceus, Bromus sterilis, Calystegia spium, Cirsium arvense, Clematis vitalba, Convolvulus arvensis, Cynodon dactylon, Dactilis glomerata, Datura stramonium, Daucus carota, Equisetum arvense, Fallopia convolvulus, foeniculum volgare, Fumaria officinalis, Galium aprine, Hypericum perforatum, Inula viscosa, Javone, Kickxia spuria, Lathirus, Linaria spuria, Lolium multiflorum, Lolium perenne, Marrubium volgare, Medicago lupolina, Melilotus alba, Melilotus officinalis, Mercurialis annua, Phalaris paradoxa, Picris echioides, Plantago lanceolata, Plantago minor, Poa pratensis, Polygonum aviculare, Polygonum lapathifolium, Potentilla erecta, Prunus spinosa, Quercus cerri, Ranunculus arvensis, Rosa canina L., Rubus ulmifolius, Rumex acetosa, Sambucus ebulus, Senecio vulgaris, Sinapis arvensis, Sorghum alepense, Stachys annua, Taraxacum officinale, Trifolium repens, Ulmus campestre, Verbena officinalis, Veronica persica, Vicia faba minor, Vicia sativa, Viola arvensis, Vitis vinifera.

to calculate the Shannon diversity index for species number and biomass weight.

\section{Results and discussion}

In Table 1 the achieved values of the Biodiversity Indicators are listed for each agro-ecosystem (Old Organic, Young Organic and Conventional) as a mean value for the years 2002/2005. In order to better underline the comparison, the indicator value is transformed in relative shortfall (discrepancy) of achieved (A) to desired (D) results according to the following formula: (A-D)/D. Discrepancy values can result between 0 and 1 (Vereijken, 1997; Vazzana et al., 1997).

The amoeba graph (Fig. 3) shows the discrepancies of the three different systems under analysis for the analysed indicators. The landscape indicator, Ecological Infrastructure Index (EII), results with no discrepancy in the Old Organic agroecosystem, some discrepancy in the Young Organic $(0,12)$ and even more in the Conventional $(0,7)$ that results with higher level of discrepancy. The Old Organic system is surrounded by strips of natural vegetation and by two hedges (one natural and the other planted) which in time reached a good complexity (high number of species of different typology): this fact confers to the system an optimal level of infrastructures, with a positive impact on the 
Table 1. List of Agro-ecological Indicators used to evaluate structural and associated biodiversity: algorithm, desired result (D), Achieved result (A) and relative shortfall (discrepancy) in the OldOrganic (OO), NewOrganic (NO) and Conventional (CO) agroecosystems management patterns of Montepaldi farm as average of 2003/2005 years.

\begin{tabular}{|c|c|c|c|c|c|c|c|c|c|c|c|c|c|}
\hline \multirow{2}{*}{\multicolumn{2}{|c|}{ Aspects }} & \multirow[t]{2}{*}{ Acronym } & \multirow[t]{2}{*}{ Indicators } & \multirow[t]{2}{*}{ Algorithm } & \multirow[t]{2}{*}{ m.u. } & \multirow{2}{*}{$\begin{array}{ll}\text { Desired } & \mathrm{L} \\
\text { result } & \mathrm{r} \\
\text { (D) } & \end{array}$} & \multirow{2}{*}{$\begin{array}{l}\text { Literature } \\
\text { reference }\end{array}$} & \multicolumn{3}{|c|}{$\begin{array}{l}\text { Achieved result } \\
\text { (A) }\end{array}$} & \multicolumn{3}{|c|}{$\begin{array}{l}\text { Relative shortfal } \\
\qquad(A-D) / D\end{array}$} \\
\hline & & & & & & & & $\overline{\mathrm{OO}}$ & $\mathrm{NO}$ & $\mathrm{CO}$ & $O O$ & $\mathrm{NO}$ & $\mathrm{CO}$ \\
\hline \multirow{5}{*}{ 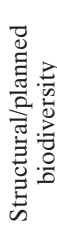 } & \multirow{5}{*}{ 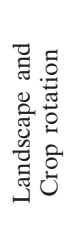 } & EII & $\begin{array}{c}\text { ecological } \\
\text { infrastructure index }\end{array}$ & $E I I=\frac{\sum \text { SupInfrEco }}{S A U}$ & $\%$ SAU & $x>5$ & (1) & 5,69 & 4,40 & 1,50 & 0 & 0,12 & 0,7 \\
\hline & & CR & crop rotation & & years & $x \geq 6$ & (1) & 4 & 4 & 2 & 0,33 & 0,33 & 0,67 \\
\hline & & SA & spices adjacency & & & $x=0$ & (1) & 0 & 0 & 0 & 0 & 0 & 0 \\
\hline & & SS & share spices & $S S i=\frac{M c / 12}{\sum_{i}^{\prime \prime} M c / 12}$ & $\%$ tot. Sp & $\mathrm{x} \leq 0,167$ & (1) & 0,28 & 0,28 & 0,5 & 0,68 & 0,68 & 1 \\
\hline & & SG & share group & $S G i=\frac{M g / 12}{\sum^{n} M g / 12}$ & $\%$ tot. $\mathrm{Gr}$ & $\mathrm{x} \leq 0,33$ & (1) & 0,33 & 0,33 & 0,5 & 0,32 & 0,32 & 1 \\
\hline \multirow{6}{*}{ 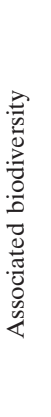 } & \multirow{6}{*}{ 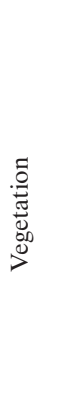 } & EIRa & $\begin{array}{l}\text { ecological infrastructure } \\
\text { arboreal richness }\end{array}$ & & n. & $x>30$ & (1) & 13,00 & 14,00 & 0,00 & 0,57 & 0,53 & 1 \\
\hline & & EIDa & $\begin{array}{l}\text { ecological infrastructure } \\
\text { arboreal diversity }\end{array}$ & $E I D=-\sum_{1}^{n} n / N * \log n / N$ & n. & $x>2$ & (2) & 2,44 & 2,06 & 0,00 & 0 & 0 & 1 \\
\hline & & $\mathrm{EIRh}$ & $\begin{array}{l}\text { ecological infrastructure } \\
\text { herbaceous richness }\end{array}$ & & n. & $x>40$ & (1) & 44,00 & 48,00 & 44,00 & 0 & 0 & 0 \\
\hline & & EIDh & $\begin{array}{l}\text { ecological infrastructure } \\
\text { herbaceous diversity }\end{array}$ & $E I D=-\sum_{1}^{n} n / N * \log n / N$ & n. & $x>2$ & (2) & 2,22 & 2,10 & 2,07 & 0 & 0 & 0 \\
\hline & & CWDn & $\begin{array}{c}\text { crop weeds number } \\
\text { diversity }\end{array}$ & $H=\sum_{i=1}^{n} p_{i} \ln p_{i}$ & n. & $x>2$ & (2) & 1,69 & 1,19 & 0 & 0,31 & 0,81 & 1 \\
\hline & & CWDw & $\begin{array}{l}\text { crop weeds weight } \\
\text { diversity }\end{array}$ & $H=\sum_{i=1}^{n} p_{i} \ln p_{i}$ & n. & $x>2$ & (2) & 1,34 & 0,86 & 0 & 0,66 & 1,14 & 1 \\
\hline
\end{tabular}

Literature reference for fixed desired results: (1): Vereijken, 1997; Vazzana e Raso 1997; (2): Shannon e Weaver, 1963.

overall biodiversity. Furthermore, over the past decade, research has accumulated evidence that long term organic systems are beneficial to biodiversity (Stolton et al., 2000).

For crop rotation, 3 over the 4 analysed indicators are below the desired values for all the three systems, even if the organic systems (Old

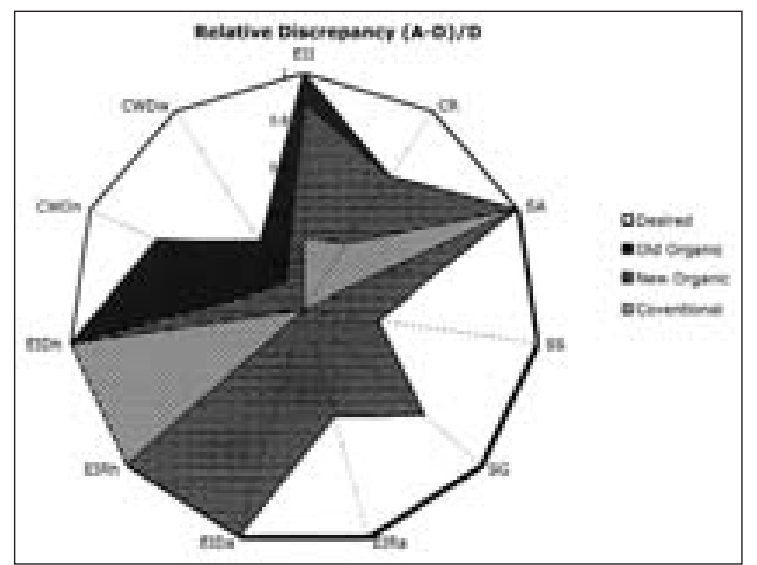

Figure 3. Relative discrepancy of achieved (A) to desired (D) results of agro-ecological indicators used to evaluate biodiversity in the OldOrganic (OO), NewOrganic (NO) and Conventional (CO) agroecosystems of Montepaldi farm as average of 2003/2005 years. A larger area corresponds to fewer discrepancies and, thus, to more desired value results. and Young) result with discrepancy values that are half of the Conventional, due to the a larger crop rotation. To improve the rotation, nitrogen-fixing, polyannual leguminous crops could be introduced in mixed farms where forage is used for animal feeding. More difficult is to find a solution in agroecosystems without animals.

The evaluation of associated biodiversity (vegetation) presents very interesting results. The diversity both of herbaceous (EIDh) and trees and shrub hedge (EIDa) plants in the ecological infrastructure is higher in the Old Organic followed by the Young Organic and the Conventional. Moreover, for that concerns the weed flora in the field, a more equilibrated community evolved in time under organic management, with higher number of species (CRWn) each represented by a lower weight of individual (CRWw).

The conventional system treated with chemical herbicide resulted with the maximum discrepancy for weed's biodiversity.

\section{Conclusions}

The analysis of agroecosystem sustainability, performed through the calculation of biodiver- 
sity indicators, evidences that the system under organic agriculture management improves each of the studied aspects over the time and it is better than conventional for every indicator.

Organic agriculture after many years of application can reach satisfaction level of biodiversity. This tendency is emphasised if we consider the associated biodiversity. The impact on biodiversity of organic farming, in relation to conventional agriculture, results in agreement with a review of comparative studies of the two methods (conventional and organic), in order to determine whether it can deliver beneficial services to biodiversity. However, organic agroecosystems considered in our experiment can be improved with larger crop rotation and the introduction of polyannual leguminous crops.

In order to fill in the gaps in our knowledge of the impacts of organic farming on associated biodiversity, there is a real need for system-level (holistic-whole-farm approach) studies before a full use of its potential role in biodiversity conservation in agroecosystems can be made.

\section{References}

Altieri M. 1999. The ecological role of biodiversity in agroecosystem. Agriculture, Ecoystem and Environment, 74:19-31.

Bockstaller C., Girardin P., van der Werf H.M.G. 1997. Use of agro-ecological indicators for the evaluation of farming systems. European Journal of Agronomy, 7:261-270.

Braun-Blanquet J. 1932. Plant sociology. McGraw Hill, London - New York.

Caporali F., Mancinelli R., Campiglia E. 2003. Indicators of Cropping System Diversity in Organic and Conventional Farms in Central Italy. International Journal of Agricultural Sustainability, 1(1):67-72.

Cappelletti C. 1976. Trattato di botanica, Utet, Torino.

Daget P., Passionate Y. 1969. Analyse phytologique des praires. Applications agronomiques. CNRS CEPE, Montpelier, doc. 48.

Dalsgaard J.P.T., Oficial R.T. 1997. A Quantitative Approach for Assessing the Productive Performance and Ecological Contributions of Smallholder Farms. Agricultural Systems, 55(4):503-533.

Hole D.G., Perkins A.J., Wilson J.D., Alexander I.H., Grice P.V., Evans A.D. 2005. Does organic farming benefit biodiversity? Biological Conservation, 122: 113-130.

Leigh R.A., Jhonston A.E. 1994. Long-term experiments in agricultural and ecological sciences. Proceedings of a conference to celebrate the 150th anniversary of
Rothmsted Experimental Station, Rothamsted, 14-17 July 1993. CAB International, Wallington, 423.

Loperz-Ridaura S., Masera O., Aster M. 2002. Evaluating the sustainability of complex socio-environmental system. The MESMIS framework. Ecological indicator, 2:135-148.

Hole D.G., Perkins A.J., Wilson J.D., Alexander I.H., Grice P.V., Evans A.D. 2005 Does organic farming benefit biodiversity? Biol. Conserv., 122:113-130.

Mäder P., Fliessbach A., Dubois D., Gunst L., Fried P., Niggli U. 2002. Soil Fertility and Biodiversity in Organic Farming. Science, 296:1694-1697.

Migliorini P. 2000. The role of soil fertility in sustainable agriculture: simulation of diverse management cases in Mugello area (Tuscany). Proceedings of International Scientific Conference of IFOAM, Basilea, 2731 August 2000.

Migliorini P., Tropea F., Vazzana C. 2005. Efficiency of organic fertilizer on Corn production and the influence of organic farming systems on soil fertility and weed biodiversity. Proceedings of International Conference of IFOAM AgriBioMediterraneo, April 2005, Ohrid, Macedonia.

Migliorini P. 2006. Evaluation of sustainability in organic system and fields of Tuscany PhD Thesis, University of Florence (in Italian), 259.

Morse S., Namara Mc N., Acholo M., Okwoli B. 2001. Sustainability Indicators: The problem of integration sustainable development Sust. Dev., 9:1-15.

Nicholls C.I., Altieri M.A. 2005. Design and implementing a habitat management strategy to enhance biological pest control in agroecosystems. Biodynamics, 27-36.

Pacini C., Wossink A., Giesen G., Vazzana C., Huirne R. 2003. Evaluation of sustainability of organic, integrated and conventional farming systems: a farm and field-scale analysis. Agriculture, Ecosystems and Environment, 95:273-288.

Pimentel D., Hepperly P., Hanson J., Dous D., Seidel R. 2005. Environmental, energetic and economics comparisons of organic and conventional farming systems. Bioscience, 55(7):573-582.

Raupp J., Pekrun C., Oltmanns M., Kopke U. 2006. Longterm field experiments in organic farming. ISOFAR, Berlin.

Shannon C.E., Weaver W. 1963. The Mathematical Thoery of Comunication. University of Illinois Press, Urbana, 117.

Stolton S., Geier B., McNeely J. 2000. The relationship between nature conservation, biodiversity and organic agriculture. IFOAM, Germany.

Stolton S. 2005. Organic agriculture and biodiversity. Dossier 2. IFOAM.

Stolze M., Piorr A., Harring A., Dabbert S. 2000. The environmental impact of organic farming in Europe. Vol VI Organic farming in Europe. University of Hohenheim, Germany. 
Van der Maaler 1972. On the tranformation of coverabundance values in phytosociology. Report Bot. Lab, Njjmegen.

Vazzana C., Raso E., Pieri S. 1997. Una nuova metodologia europea per la progettazione e gestione di agroecosistemi integrati ed ecologici: applicazione in un'area agricola toscana. Rivista di Agronomia, 31:423-440.
Vereijken P. 1997 A methodical way of prototyping integrated and ecological farming system (I/EFS) in interaction with pilot farm. European Journal of Agronomy, 7:235-250.

Vereijken P. 1999. Manual for prototyping Integrated and Ecological Arable Farming Systems (I/EAFS) in interaction with pilot farms. ABD-LO, Wageningen. 